\title{
INTRADUCTAL PAPILLOMA OF SALIVARY GLAND
}

P. Narmadha1, Gowri Sankar R², Rehana Tippoo³, P. Viswanathan4, U. Manohar ${ }^{5}$

\section{HOW TO CITE THIS ARTICLE:}

P. Narmadha, Gowri Sankar R, Rehana Tippoo, P. Viswanathan, U. Manohar. "Intraductal Papilloma of Salivary Gland". Journal of Evolution of Medical and Dental Sciences 2014; Vol. 3, Issue 20, May 19; Page: 5622-5625, DOI: $10.14260 /$ jemds/2014/2638

ABSTRACT: A case of intraductal papilloma of a parotid gland is presented because of its rarity. The lesion was clinically diagnosed as retention cyst of salivary gland. The excised specimen was histopathologically diagnosed as intraductal papilloma of parotid gland. According to the microscopic finding papillary growth of ductal epithelium with fibrovascular core projecting in to ductal space was seen.

KEYWORDS: Intraductal papilloma, Salivary gland.

INTRODUCTION: Intraductal papilloma of parotid gland is a rare salivary gland tumor ${ }^{1,2}$ and only a few cases have been reported in literature.

CASE REPORT: The patient developed a peanut size swelling just below his left ear lobe which progressively increased in size and caused cosmetic discomfort to the patient which brought him to the surgeon.

On examination a $3 \times 3 \mathrm{cms}$ firm to cystic swelling was seen just below the earlobe. Margins were well defined. Swelling was freely mobile and non-tender.

RADIOLOGIC FINDINGS: Ultrasound and CT scan was done-both pointed towards a benign cystic lesion. Left superficial parotidectomy was done. Specimen was sent for histopathological examination which was diagnosed as intraductal papilloma of parotid gland.

FNAC FINDINGS: Smears studied revealed cytological finding highly suggestive of benign cystic papillary lesion of the parotid gland.

MACROSCOPIC FINDINGS: A grey black, grey brown specimen measuring $2.5 \times 1.5 \mathrm{cms}$ was sent. On cut section a cystic space measuring $1.5 \times 1 \mathrm{cms}$ filled with serous fluid was seen.

MICROSCOPIC FINDINGS: Sections studied revealed normal salivary gland tissue along with a cyst lined by benign low cuboidal to flattened cells. There were papillary structures composed of tubules of varying size lined by two layers of benign cuboidal to low columnar cells; some of the tubular structures revealed proteinaceous material. They were separated by thin fibrous tissue. Areas of hyalinization were also present. The cyst wall contained scattered inflammatory cells comprising of lymphocytes.

Features were consistent with intraductal papilloma of salivary gland

DISCUSSION: Intraductal papilloma of parotid gland is a rare salivary gland tumor most commonly seen involving excretory ducts of intraoral minor salivary gland, buckle mucosa and palate 3 , 4.0nly few 
cases have been reported to affect the major salivary gland. The tumors form palpable nodules without any special features and the diagnosis is only made by Histopathological examinations.

Cytological findings are orderly papillary clusters of benign epithelial cells with oncocytic features some showing sebaceous differentiation.5,6

Clinically patients present with a painless oral or submucosal mass. Majority of patients are in their sixth or seventh decades. Men and women were equally affected. Grossly uniloculated cystic lesion can be seen. Microscopy will reveal cystically dilated duct with papillary epithelial proliferation composed of branching or anastomosing proliferation of single or double layered tall columnar cells with fibrovascular core.7,8,9 The cyst is in continuity with the salivary gland excretory duct. Tumor does not proliferate beyond the cyst wall. ${ }^{10}$ The lesion is surrounded by a thick fibrous capsule infiltrated by chronic inflammatory cells.

\section{DIFFERENTIAL DIAGNOSES:}

1. PAPILLARY CYSTADENOMA: They are multicystic structures.

2. INVERTED DUCTAL PAPILLOMA: Arises at interface of the salivary gland duct with the mucosal surface epithelium whereas intraductal papilloma arises more proximal to a duct.

CONCLUSION: Intraductal papilloma arising in salivary gland may show acinar differentiation, ductal cyst by obliteration and progress to adenocarcinoma. To prevent this complication surgery is the only mode of treatment.

\section{REFERENCES:}

1. Jansisyanont P, Blanchaert RH, Jr., Ord RA. Intraoral minor salivary gland neoplasm: a single institution experience of 80 cases. International Journal of Oral and Maxillofacial Surgery.2002; 31(3):257-261.

2. Ellis GL, Auclair PL. Ductal papillomas. In: Ellis GL, Auclair PL, Gnepp DR, editors. Surgical Pathology of the Salivary Glands. Philadelphia, Pa, USA: Saunders; 1991. pp. 238-252.

3. Brannon RB, Sciubba J.J, Giulani M. Ductal papillomas of salivary gland origin: a report of 19 cases and a review of the literature. Oral Surgery, Oral Medicine, Oral Pathology, Oral Radiology, and Endodontics. 2001; 92(1):68-77

4. Brannon RB, Sciubba J.J. World Health Organization classification of tumours. In: Barns L, Eveson JW, Reichart P, Sidransky D, editors. Pathology and Genetics of Head and Neck Tumours. Lyon, France: IARC; 2005. pp. 272-273.

5. Hara H, Oyama T, Omori K, et al. Fine needle aspiration cytology of an intraductal papilloma originating in a sublingual gland: a case report. Acta Cytologica. 1999; 43(3):457-463.

6. Nagao T, Sugano I, Matsuzaki O, Hara H, Kondo Y, Nagao K. Intraductal papillary tumors of the major salivary glands: case reports of benign and malignant variants. Archives of Pathology and Laboratory Medicine. 2000; 124(2):291-295.

7. Tomonao A, Kishino M, Masuda $\mathrm{T}$, et al. Intraductal papilloma arising from sublingual minor salivary gland: case report and immunohistochemical study. Oral Surgery, Oral Medicine, Oral Pathology, Oral Radiology, and Endodontology. 2009; 107:e34-e37.

8. Sahu KS, Singh PK, Singh BP, et al. Breast intraductal papilloma. Jurnalul de Chirurgie (Iaşi) 2012;8(2) 


\section{CASE REPORT}

9. Greenburg MS, Gick M. Burket's Oral Medicine Diagnosis and Treatment. 11th edition. Ontario, Canada: BC Decker; 2003.

10. Ishikawa T, Imada S, Ijuhin N. Intraductal papilloma of the anterior lingual salivary gland. Case report and immunohistochemical study. International Journal of Oral and Maxillofacial Surgery.1993; 22(2):116-117.

\section{MICROSCOPIC PICTURES}

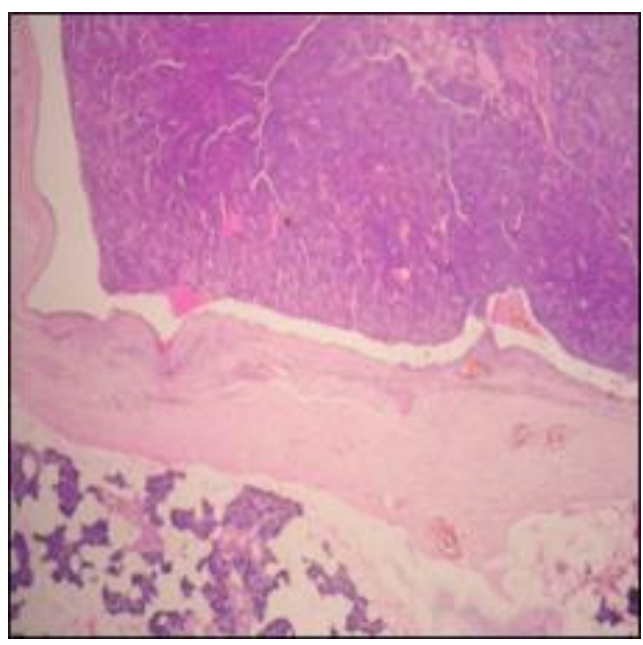

Fig. 1: 10x

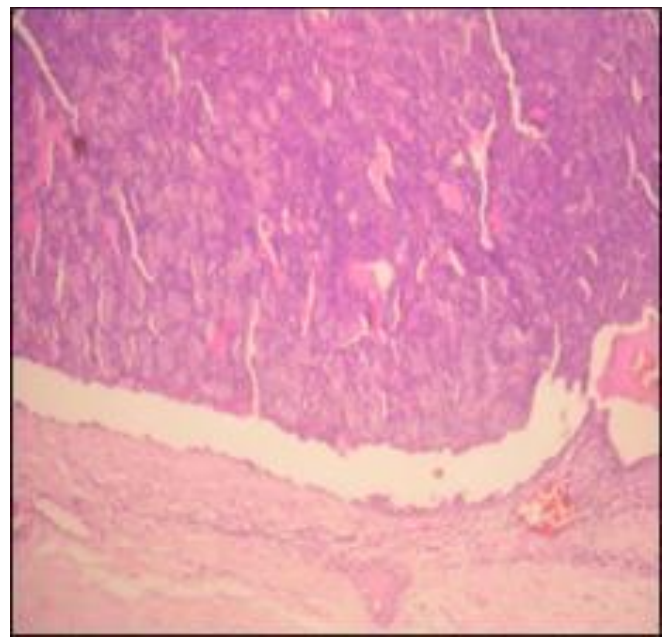

Fig. 2: 20x

Cyst lined by benign low cuboidal flattened cells is seen with papillary structures composed of tubular structures lined by double layer of cuboidal to low columnar cells which are separated by thin fibrovascular core.

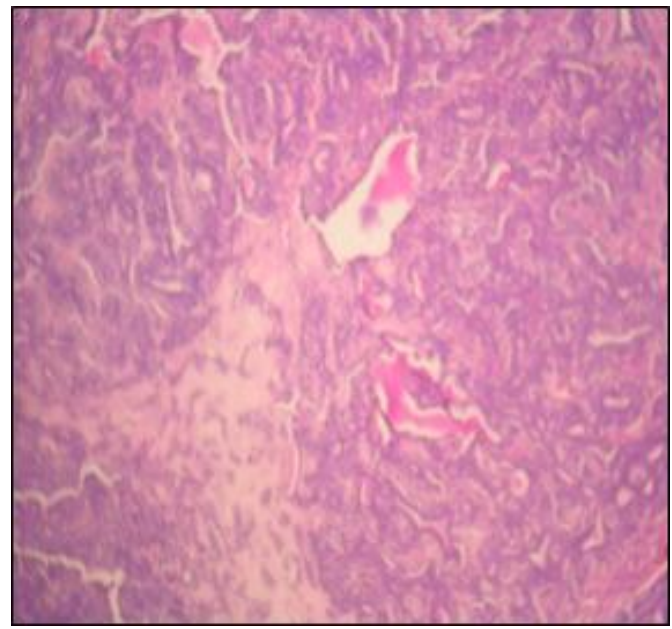

Fig. 3: 10x

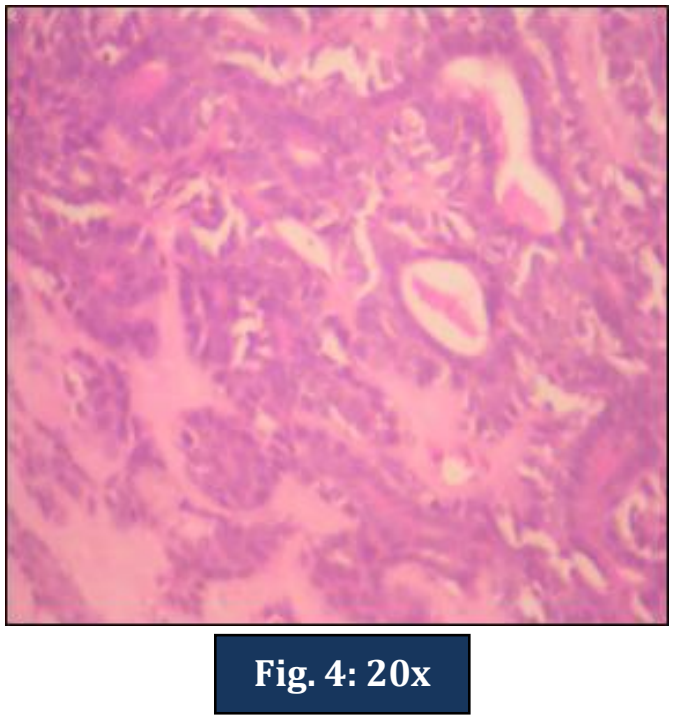




\section{CASE REPORT}

\section{Areas of hyalinization}
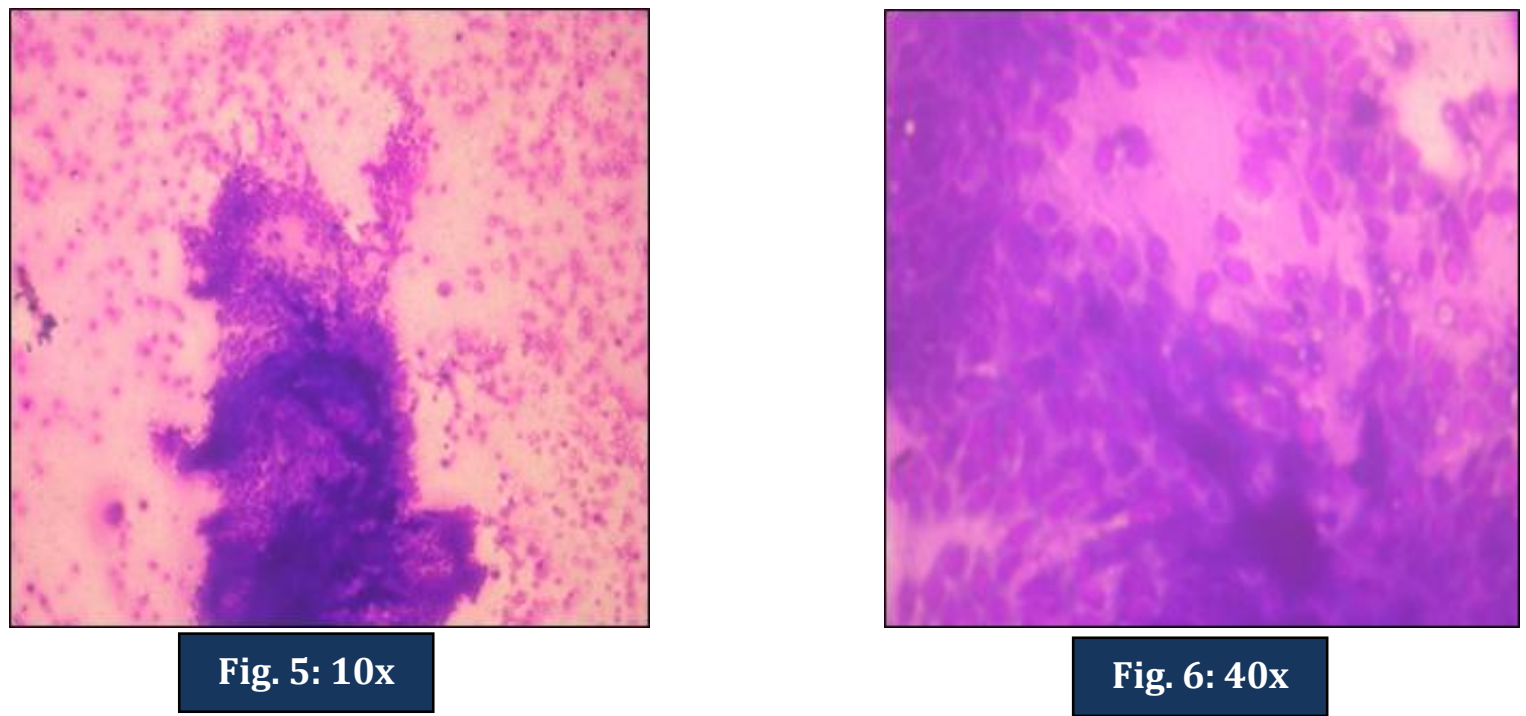

Clusters of cells of ductal epithelial origin with a vague papillary pattern with a fibrovascular core are well differentiated with fibrous stroma.

\section{AUTHORS:}

1. P. Narmadha

2. Gowri Sankar R.

3. Rehana Tippoo

4. P. Viswanathan

5. U. Manohar

\section{PARTICULARS OF CONTRIBUTORS:}

1. $2^{\text {nd }}$ Year Post Graduate, Department of Pathology, Rajah Muthiah Medical College, Annamalai University.

2. $3^{\text {rd }}$ Year Post Graduate, Department of Pathology, Rajah Muthiah Medical College, Annamalai University.

3. Professor, Department of Pathology, Rajah Muthiah Medical College, Annamalai University.

4. Professor, Department of Pathology, Rajah Muthiah Medical College, Annamalai University.
5. Professor, Department of Pathology, Rajah Muthiah Medical College, Annamalai University.

\section{NAME ADDRESS EMAIL ID OF THE CORRESPONDING AUTHOR:}

Dr. P. Viswanathan,

Professor, Department of Pathology,

Faculty of Medicine,

Rajah Muthiah Medical College,

Annamalai University,

Chidambaram-608002,

Tamilnadu, India.

E-mail: drpviswanathan2013@gmail.com

Date of Submission: 11/04/2014.

Date of Peer Review: 12/04/2014.

Date of Acceptance: 25/04/2014.

Date of Publishing: 19/05/2014. 